Paul Hedges*

\title{
Encounters with Ultimacy?: Autobiographical and Critical Perspectives in the Academic Study of Religion
}

https://doi.org/10.1515/opth-2018-0027

Received March 10, 2018; accepted August 13, 2018

\begin{abstract}
Ultimacy," it is argued, is not an area that academic studies in theology nor the study of religion can properly investigate; nevertheless, it is also illegitimate to argue therefore that claims to it are simply linguistic power plays. Using an autobiographical methodology, the author explores how their own "imagined" "mystical" experience and scholarly studies may shed light on approaching the study of religious experience, noting particularly work by Rudolf Otto, Robert Sharf, Gregory Shushan, and Ann Taves. Reflections are offered on studying religious experience, approaching ultimacy, and the relationship of theological and religious studies. Moreover, some critical and decolonial perspectives are brought to bear both on the author's own work, academic studies, and contemporary debates around studying what may be termed "mysticism" or religious experience. The author also argues that the autobiographical and reflexive model offered herein may be a useful perspective for scholarship in the study of religion.
\end{abstract}

Keywords: Religious experience, mysticism, autobiography, methodology, reflexivity, religious studies, theology, ultimate, decolonization

\section{Introduction: Introducing my problem with this issue}

This article is, to some extent, written against the intent of this special issue: I do not claim to know what "marks of ultimacy" are. Indeed, I would argue that academic theology, or studies in religion, should not legitimately explore this area. (It is possible to study ways traditions have conceptualised what they understand "ultimacy" to be, and to note their internal markers for recognising it; but that is quite different from attempting the first-order theological claim of identifying and comparing what "marks of ultimacy" may be ${ }^{1}$ ). Nevertheless, I am writing a paper that is both autobiographical as well as academic, speaking about my own encounters with "ultimacy" to deconstruct them. Indeed, I also write against the concept of "ultimacy". Paradoxically, therefore, I actually engage in the act that I am writing against; stating what this concept is for me. I beg my reader's forgiveness for what may therefore be an idiosyncratic and at times,

1 While demarcating areas we can meaningfully distinguish, there is no clear dividing line between first-order and second-order theology (respectively: confessional speech; and, academic discourse on that confessional speech), nor between second-order theology and the secular discipline of the academic study of religion. This is despite very partisan wall building and rhetoric by some in each camp. I do not intend to explore this directly here, but it is an undercurrent of the paper. On some issues related, see Hedges and King, "Is the Study." I may note that as this article explores many of these ideas in an autobiographical fashion, I will often cite my own work as indicative of how I have come to understand and interpret these concepts, though also citing the wider scholarship which has either informed my own views or is part of the wider scholarly conversation.

*Corresponding author: Paul Hedges, Nanyang Technological University, Singapore; E-mail: ispmhedges@ntu.edu.sg 
perhaps, non-academic article. Nevertheless, I hope that readers will find it instructive and useful as a reflection on a personal path of discovery relating to how "ultimacy" may be viewed and discussed by one (part-time) theologian and (part-time) scholar of religion.

Before moving to the body of this article, itmay be useful to clarify someissues. Mundanely, at a descriptive phenomenal level, texts understood broadly (both religious and secular ${ }^{2}$ ) do have markers of ultimacy: they claim to be "revelation"; they relate the words of some "deity", "transcendent power", or "transphenomenal reality"; or, make claims to truth. Such claims may be studied. Nevertheless, most traditions also suggest that whatever "ultimacy" may be, it transcends any human classification or conceptualisation; ${ }^{3}$ we may at best - to use the clichéd old Zen phrase - speak only of fingers pointing at the moon. While we may talk about those fingers, and put them in comparative perspective, the moon itself appears off limits. However, I do not intend to look at such phenomenological issues. But this raises the issue I am grappling with: how any academic tradition may speak of "ultimacy" as anything other than a human linguistic concept? While writers like Rudolf Otto are part of "classical" theory (his noumenal being a category of "ultimacy"), his work today is recognised as theological rather than phenomenological. ${ }^{5}$ Indeed, all Otto had access to was human discourse. ${ }^{6}$ In line with certain critiques of Otto, this paper is concerned with the critical methodology of studying what may broadly be termed "religious experiences". To this end, I begin with an autobiographical reflection, which describes my own grappling with experiences that I once held to signify "ultimacy", before moving onto theory in the academic study of religion. From there, I will move to a set of reflections on a range of related themes, both more personal and more academic. I do not claim to offer a new grand theory or definitive conclusion, but I will seek to draw these strands together in terms I hope other scholars and students may learn from. Various threads are therefore woven both thematically, and in an ad hoc manner, through this paper. Moreover, at various points I also offer an excursus into theoretical and contextual issues. For scholars familiar with the related terrain these may simply be skipped over, but anticipating readers from a variety of disciplinary perspectives, they are provided to fill in some background.

\section{The autobiographical bit}

There was a time when academic work was viewed as an entirely objective and impersonal affair. Rational selves employed common languages of impartial analysis to order the world into systematic codes of knowledge. Within the humanities and social sciences, developments in recent decades have dismissed such an idealistic standpoint: we all come with agendas, prejudices, and baggage. ${ }^{7}$ As such, I could write this autobiographical section within the context of an epistemologically founded methodology to locate myself as an author; certainly a decolonizing approach would argue that commitment and objectivity are not distinct, so a personal approach and an academic approach should not be separated. ${ }^{8}$ Indeed, that is

2 The terms "secular" and "religion" are contested, see: Fitzgerald, Discourse. While the author agrees with Fitzgerald's historical analysis about the way that "religion" and the "secular" are created as binary oppositions, I cannot go along with the conclusions drawn from this, see Hedges, "Discourse." For the purposes of this paper, they are used to mark arenas of life that will typically be understood by these terms within the context of modern Western academic work in general.

3 This claim is explored by John Hick as part of his argument for the pluralist hypothesis, and has more recently been expanded upon by Perry Schmidt-Leukel. See Hick, An Interpretation, 236-40, and Schmidt-Leukel, God, 179-87. While both authors are making, more or less, theological claims in these works, nevertheless, the arguments cited are broadly descriptive of claims made in the traditions surveyed.

4 See Otto, The Idea, 5-7.

5 See, e.g. King, "Mysticism”, 328-30.

6 Otto himself noted that, as "mysterium", the numinous experience was "wholly other" and so beyond any human conceptualisation in words or description, and even when he speaks of "direct means" of expressing it he notes that this is merely suggestive or always refers to something else, see Otto, The Idea of the Holy, 25-30, 60-61. We take up related themes, and also revisit Otto, later in the article.

7 Flood, Beyond Phenomenology. For a further discussion, see Excursus 5.

8 See, e.g. Wilkins, “Taking it," or Mitchell, Just Who, and on a decolonizing approach within Africana or Black Studies, see Agozino, "Committed Objectivity” (see Excursus 5 on this). 
partly my aim. However, it is also here as what I may term "data" to be examined and explored. ${ }^{9}$ I should state, though, that what I am setting out here is something which for many years I found very difficult to talk about and which I have only ever revealed to very few people. It is therefore something of a personal discovery and self-disclosure at the same time.

Brought up within a fairly traditional British family, I was baptised as an Anglican at a young age. My parents were church-going and so attending Sunday School and then church each week was a regular part of my early life. Indeed, Christian devotional practice was also part of my early adult life, as I was a keen supporter of our college chapel at university (though I did not always sit easily amongst some of the more conservative theological and ecclesiastical views). The Anglicanism of my early years was of a broadly middle of the road type, that is neither high church nor low church and theologically broad and tolerant of diverse standpoints; although these were things I was not really consciously aware of. Therefore, growing up, there was a sense of "ultimacy" in my family and cultural background. One particular event brought this to a head. I was perhaps seven or eight years old at the time, we were staying at the house of an aunt and uncle. My aunt was of a more evangelical inclination, a style of worship and theology, which even from much younger, I knew was not my cup of tea. However, on this particular day, we were all taken to an evening revival meeting at the local Anglican parish church (a plain but beautiful medieval building). The service was quite traditional British low church in terms of traditional hymns and preaching, but ended with the laying on of hands by the priest who had led the service and some of his assistants. As a family, we were with one of these assistants, quite a young and I think inexperienced evangelist, who took turns in laying on of hands to us. It was clear to me that my aunt expected or hoped that we would feel "the spirit" and have the experience of being "born again". My parents, I remember, were somewhat nonplussed by this rather overtly emotive and slightly "un-Anglican"/ "un-British" approach. Certainly, in my own Anglican background at the time this really was not what I was used to, nor did I really have any sense of what we were supposed to experience. Nevertheless, when it came to my turn for the laying on of hands, I did experience something. It is something which I can only characterise as perhaps the most powerful and intense experience of my life. As I tried to explain/ describe it to myself later, I would use the phrases "unburning fire" or "pure and unconditional impersonal love". But it was not one but both of these at the same time; and more. Later, terms like "unbeing" or "pure being" would also be ways to help me think of it. At the time, though, it was not something that my conceptual world could really handle. When I opened my eyes after what seemed like forever, but must have been a few seconds, I could see that the young evangelist looked just as shocked as I was. I assume he must - perhaps for the first time - have felt something too. When asked, however, I simply said that I had felt nothing. Even when pressed, and when I saw the rather confused look in the young evangelist's eyes. Perhaps, despite being a good young Anglican, I really had no time for being "born again" and what that may entail. But also, simply, I was scared and had no words to describe or explain what I had just felt. Perhaps I also feared that whatever words were put on it would be other people's words. Words that wouldn't describe my experience. As such, for many years, this was simply a secret experience that I carried with me.

As I grew older, some of the searing "unburning fire" that told me that there was some spiritual reality to the universe passed to a memory, and certainly for a while I forgot it; or, rather, it passed from my conscious memory to some closet of my mind. Nevertheless, I found myself unable to accept that there was not a spiritual reality or "ultimacy" to the universe. In short, the experience was so real that it could not be questioned. I was aware of atheist arguments; my best friend through most of secondary school was a committed and intelligent atheist and we discussed such things. Yet this experience stayed as some kind of bedrock within my thoughts: that there must be more to the universe than sheer matter. The memory of it came back to me in my later teenage years through reading some Buddhist texts (I believe on Zen). The thought came to my mind that the Buddhist author had experienced exactly what I had experienced. With this, the memory came clearly back to me and stayed with me. At university, as I read for my undergraduate degree in Religious Studies and Theology (a joint degree across what were two disciplines), other readings

9 This term relates to McCutcheon's well-known dictum that (confessional) theology is "data" for scholars in the study of religion rather than "method”, see McCutcheon, The Discipline, 93. 
also brought it to my mind. While, at first, it was mainly in reading non-Christian writings that I found things that resonated with my experience, when I came across Meister Eckhart I again got a clear sense that what he was talking about was my experience. If you like, I was sure that in certain Buddhist texts, in Meister Eckhart and some other Christians mystics (as they were termed), and in my own life, the self-same experience was being described. Certainly, the words were very different, and the categories seemed often antagonistic; nevertheless, I strongly felt that we were all talking about the same thing - I simply felt that this was another way of putting that indescribable experience into words. Perhaps, most systematically, I felt the experience described when reading about certain Hindu tantric experiences relating to kundalini, for these conceptualised precisely what I had felt in bodily terms.

As noted, the experience seemed to me to be an "impersonal love". Therefore, I found it hard to relate to ways (particularly evangelical) Christians, spoke about an experience of the "divine" as personal. Yet, I could see why people spoke that way: it was hard to understand love as impersonal. Therefore, I systematised an explanation that resonated with pluralist or perennialist accounts (see Excursus 1), that created a hierarchy of interpretations: impersonal interpretations represented a full understanding; impersonal interpretations showed a lower level of understanding - those who spoke this way did not fully "get it". With time, and my development as an academic and critical thinker, I came to not only scrutinise my own conceptualisation, but also to critically assess my own experience.

\section{Excursus 1: Perennialism and pluralism}

While certainly not identical, many critics lump these two together. Moreover, perennialism is seen as one pathway towards a pluralist stance..$^{10}$ The basic claim of perennialism is that there is a core, or common, underlying mystical experience which people variously describe depending on their theological or cultural system. ${ }^{11}$ That is, it asserts that every religion is essentially "the same" though they may manifest differently in external (read: superficial) aspects, though they see many being attached to these externals as though it were the true core. A pluralist stance, most commonly associated with John Hick, ${ }^{12}$ is typically seen as part of the tripartite theology of religions systematization developed by Alan Race. ${ }^{13}$ Asserting a common core experience is not essential to a pluralist stance, but as a theological stance it argues that all religions (at some level, i.e. ethical, spiritual/ mystical, ontological) all point towards the same truth, reality, or meaning.

For many years, this experience remained with me as an unchallengeable "mark" of "ultimacy". Notably, from my own experience, I can see the futility of many arguments to get "religious people" to abandon their convictions through rational argument; ${ }^{14}$ experiences like this are simply more compelling. Nevertheless, continued reflection and academic reading relating to spiritual experiences, led me to recognise that it could have simply been an event in the brain (or, more broadly, in my embodied self). While uniquely compelling, and more vivid, potent, and powerful than anything I have known before or since, it could simply have been the release of various chemicals and an entirely natural event. This was not a single time realisation. Nevertheless, it was an important breakthrough for me: there may be no "ultimacy".

I became critical of the kind of pluralist and perennialist theological categories that I used to interpret my own experience, and thereby to categorize others. Nevertheless, I continue to classify myself as an Anglican (the tradition into which I am initiated) "pluralist”. Though pluralism is currently unfashionable in academic theology, for various reasons - which I have written about at length elsewhere - I find this a

10 See Schmidt-Leukel, "Pluralisms.”

11 For an overview of the Perennial Philosophy school, see Oldmeadow, "Metaphysics," and a discussion of some contemporary Islamic forms, see Jawad, “A Muslim,” 346-56.

12 Especially in terms of his magnum opus on the pluralist hypothesis, Hick, An Interpretation.

13 On pluralisms, see Hedges, Controversies, 109-45, and on the Theology of Religions typology, see ibid., 9-30. The most up-todate discussions on the typology and pluralism are in Harris et. al., Twenty-First Century.

14 The terms "religious people" and "non-religious people" are very problematic categories so used here as a shorthand, see Hedges, Towards Better, 2-3. 
more plausible and theologically satisfying standpoint. ${ }^{15}$ If there is an "ultimacy", I certainly hope it is one in line with the pluralist hypothesis broadly conceived. However, I do not remain certain that there is any "ultimacy". I am agnostic - a more or less sceptical one depending on my ongoing journey. ${ }^{16}$ Therefore, as a theologian, I am deeply sceptical of appeals to "ultimacy". Moreover, as a (non-confessional) scholar of religion, I also have problems with the category academically. I now turn to this other angle of what could also be described as autobiographical literature: giving a picture of myself as a scholar of religion.

\section{Talking from the religious studies angle}

Between confessional theology, academic theology, and the academic study of religion, I would suggest we see something of a continuum, or range of overlapping Venn diagram type circles, rather than distinct and opposing regimes of practice and thought, notwithstanding that some would want to mark such distinct disciplinary boundaries. This latter stance is quite understandable. To mark its place as a "respectable" scientific endeavour within a broadly secular set of likeminded humanities and social sciences, the academic study of religions (variously religious studies, the history of religions, or similar) has often had to make a case that, whatever it does, it is not confessional theological work. ${ }^{17}$ This is not the place to enter into the minutiae of these debates, nevertheless a sense that some difference exists between more theological work and more religious studies approaches is implicit in this paper. In light of the partially autobiographical nature of this paper, some positioning of myself within these disciplines is needed.

As mentioned, my first degree was a joint degree between Religious Studies and Theology as two distinct disciplines (in the UK context). However, given that it was in a broadly secular British university in a department of Theology and Religious Studies (later, Islamic Studies was added to the departmental nomenclature) it was not a divide between a non-confessional approach and a confessional one. Theology was broadly religious studies about Christianity, while Religious Studies concerned other religious traditions. Nevertheless, some sense of disciplinary divide existed. I believe all my theology tutors were Christian priests (without necessarily implying they accepted any form of Christian orthodoxy, or practiced as such), while most of my religious studies ones were not (though we had lecturers and professors who belonged to a variety of religious backgrounds, and had at least one visiting professor of Buddhism who was classified as a Buddhist priest). However, on neither side of this largely imaginary divide, did I ever get a sense that what we were studying was "ultimacy". There were students pursuing their studies with an eye to eventually becoming priests or broadening their existing religious/ spiritual paths in whichever tradition they belonged, or to understand their place within no tradition. Others were also clearly agnostics or atheists. None of the tutors in theology nor religious studies, however, saw it as in their role as academic staff to guide us towards any sense or understanding of "ultimacy". If such discussions took place it was as private individuals or in other capacities.

I certainly think it fair to say that my sense of critical scholarship has progressed in the years since then, through my postgraduate studies, but especially in my work as a professional academic teaching and researching within universities. Probably, as an undergraduate, the closest we got to studying the issue of "ultimacy" would have come in an undergraduate course on "Mysticism". We studied the Christian tradition and other "world religions," 18 as well as looking at the analytic literature on constructivist,

15 For a more academic account, see Hedges, Controversies, or for a more accessible account, see, Hedges, "Is Christianity.” I should note here that this is taking a theological stance on the positions, and from a more "outsider" or scholarly stance we can note many problems with such positions, see, for instance, McCutcheon, Critics, 43-56, also discussed in Hedges, Understanding Religion.

16 For explorations of these issues, see Hedges, Towards Better.

17 On these debates in various global contexts, see Hedges and King, "Is the Study," 43-6.

18 The terminology "world religions," and even "religion" is problematic within critical contemporary scholarship. Back-inthe-day, while sometimes questioned by my more "theoretical” lecturers, it represented the prevailing discourse. On issues with "world religions" and "religion”, see King and Hedges, "What is Religion?”, and Hedges, "Multiple," 51-6 - the latter in particular sets out why despite my rejection of the so-called "World Religions Paradigm" I believe we can continue to employ the term "religion" as a meaningful descriptor. 
perennialist, and other approaches (see Excursus 2). At that time, while seeing the values of constructivist approaches, my prevailing sensibilities aligned me with the broadly perennialist stance, though critical of some perennial philosophy as naïve. My "experience" that a common spiritual source underlay the different religions underpinned this, though I came to believe that quite possibly there were various different mystical experiences rather than a single common one.

\section{Excursus 2: Constructivism and perennialism in mysticism}

Broadly, debates in the study of mysticism have swung between two poles: constructivist and perennialist. ${ }^{19}$ The constructivist side argues that any supposed religious/ spiritual/ mystical experience (the terms depend upon the author - but see also below) are the product of linguistic and social conditioning. There is no original or core experience, rather the tradition in which one is nurtured gives birth to specific experiences. This is based in largely social constructivist and critical theory approaches arising from around the 1970s. The perennialist side in this debate - aligned to (but not coterminous with) the perennialist stance outlined above - argues that experiences are prior to doctrinal or cultural overlays. There is an original experience which is the basis of religion. Such an approach could be traced back to Schleiermacher and his views on experience as the original foundation of religion. It is often deemed that a constructivist approach is non-religious, whereas a perennialist one is religious, however, this is not necessarily so. An approach like George Lindbeck's linguistic-constructivist approach to theology sees experiences as created from tradition, while some cognitive sciences approaches may posit common experiences arising through shared evolutionary or brain structures. ${ }^{20}$

Contemporary academic approaches remain sharply polarised. Through the intervening decades, the constructivist critique has been broadly dominant. It has fitted what may inadequately - given the loaded and contested nature of the term - be termed the "postmodern" sensibility that every religion is a distinct and discrete unit. Alterity is stressed over similarity. We could link this to various trends which have seen comparative studies move from the commonly accepted modus operandi of the discipline to a somewhat side-lined and maligned field seen as naïve and best for dilettantes rather than professional scholars; though this has started to change in recent years. ${ }^{21}$ Engaging these debates has been part of my changing stance on my own experience. As a teacher, presenting arguments to students has helped me think through my own position. While more critical of perennialism, I am not wholly in the constructivist camp; while constructivism is compelling, it is not entirely convincing. Arguments for certain similarities and common ground between traditions and experiences rest, I believe, on quite compelling evidence and argumentation. ${ }^{22}$ In terms of "ultimacy", seeing common grounds is certainly not (as some opponents may caricature) a necessarily perennialist or theological stance. From areas such as the cognitive science of religion, we may posit aspects of a common human experience (not to be seen as the same as, nor stereotyped as, certain Enlightenment views about a common and generic humanity) at a species level. This means that around the globe, and through perfectly natural means, similar sets of responses to the world may arise. ${ }^{23}$ This is an important aspect of this paper's overall argument: experiences of some broadly "mystical" character are far from evidence that they respond to any form of "ultimacy" in the universe.

While I have headed this section "Talking from the Religious Studies Angle", the point needs to be made that there is not simply one "angle" in this discipline, or any other. Rather, we see various perspectives

19 Two classic works and theorists in the debate remain, Stephen Katz, Mysticism on the constructivist side, and Robert Forman, Mysticism who argues for the commonality of experiences across traditions. An old but still worthwhile collection on debates is Woods, Understanding, while a recent collection with some important essays is Schmidt, The Study. For a broadly critical survey see King, "Mysticism." We will delve into these debates in more depth as we proceed.

20 On these later two, see Lindbeck's classic, The Nature, and Smith, Thinking About Religion, 95-117.

21 On this, see Patton and Ray, A Magic, and Schmidt-Leukel and Nehring, Interreligious, see also Hedges, "Comparative Methodology." It is also addressed in Hedges, Understanding Religion.

22 I have suggested this before, in Hedges, Controversies, 178-81, noting particularly the work of Diana Eck and John Keenan cited there.

23 For some accounts of this, see Smith, Thinking, 96-8, 111-15, and Luhrmann, “Building.” See also Boyer, Religion Explained. 
- beyond theological categories - to discuss "mystical" experiences and "imagined" (see Excursus 3) experiences of "ultimacy". "Classical" religious studies scholarship, in which I was trained, was broadly phenomenological and comparative, e.g. asking questions about mysticism in Buddhism and Christianity. Subsequently, my scholarship has been influenced by critical theories about what "ultimacy" may mean and how it is deployed. Questions from such religious studies perspectives may include: why traditions believe that their teachings or practice relate to "ultimacy"; what "ultimacy" means in relation to specific traditions; and whether we are even thinking about any common sense of "ultimacy". However, it goes further to ask "political" questions: who benefits from the language of "ultimacy"; what interests are served, and whose views are side-lined, ignored, or delegitimised by specific languages of or claims to "ultimacy"? Through these latter questions we can establish how claims to experiences of ultimacy play out within traditions, and how voices are silenced, and certain regimes of thought established. ${ }^{24}$ Importantly, even these critical perspectives can stem from perspectives that are predominantly wedded to traditional (white, patriarchal, and oppressive) standpoints, as a decolonizing approach may argue. This paper aligns with approaches that criticize some traditional modes of scholarship which deny indigenous agency in making sense of modes of experiencing and knowing. ${ }^{25}$

\section{Excursus 3: "Imagined" experiences}

In using the term "imagined", I am invoking concepts associated with such scholars as Charles Taylor ("the social imaginary") and Benedict Anderson ("imagined communities"), which is to say that we have to understand such claimed experiences, and descriptions of them, within social and cultural worldviews more broadly. ${ }^{26}$ Experiences are created ("imagined") as social constructs. I do not mean that I know a priori that they do not relate to some "ultimate reality" and are therefore merely "imaginary" as we may typically use this word in English. While some scholars from what are seen as critical standpoints seem to hold that some form of atheist epistemology is incumbent upon a "secular" scholar of religion, this appears to me to be simply untenable ideology. It goes beyond the scope of this paper to address this issue adequately, as such I leave it as a note alongside my particular use of "imagined" in this paper.

In tracing influences on my scholarship and academic trends, I should note that my standpoint both aligns with, but also contests, some dominant standpoints. There are limitations in much religious studies scholarship. Indeed, if it only asks questions about power relations and the social construction of categories it fails to engage other important issues. To discuss this, in relation to religious experiences, I turn to the influential scholar Robert Sharf. He contests traditional scholarship which has cast "spiritual experience" or the "mystical" as a distinct category (see Excursus 4). Rather, Sharf argues, medieval Chinese Zen texts do not record specific experiences, rather they reflect power play and textual arguments about lineages and doctrinal disputes. ${ }^{27}$ The concept of the "religious experience" is, he believes, a Western category, and so all we can legitimately do is look at power.

\section{Excursus 4: "Mysticism" and "religious experience"}

I deploy (in various formations) "mysticism," "spirituality," and "religious experience" in inverted commas suggesting their disputed and provisional nature. ${ }^{28}$ It goes beyond the limits of this paper to discuss in any depth the etymologies and academic evolution of these terms. However, it is necessary to point to reasons for at least querying their status. To note, often (but not always) "mysticism" was employed to

24 Scholars will readily note the influence of Bruce Lincoln and others in this formulation, especially his well-known "Theses on Method" (Gods, 1-3), and "How to Read." For perhaps the most thorough-going approach to introducing religion from such a standpoint, see Martin, A Critical. A discussion on the importance of such scholarship, but also a critique of it, will be found in Hedges, Understanding Religion.

25 See Agozino, “Committed Objectivity," and Hedges, "Decolonizing.” This will be more fully worked through in Hedges, Understanding Religion.

26 See Taylor, Modern Social Imaginaries, and Anderson, Imagined Communities.

27 See Sharf, "Experience”, and Sharf, "Buddhist."

28 For an overview, see King, "Mysticism." 
refer to what were seen as "elite" forms of religious experience, with spirituality and religious experience being broader. Traditional religious studies scholarship tended to see each as universal categories: every religion had its brand of mysticism and comparable (even if distinct) religious experiences as part of this. In this schema, Sufism was Islamic mysticism, figures such as Eckhart, Teresa of Avila, and John of the Cross represented Christian mysticism, meditation was Buddhist mysticism, and the Dao De Jing was seen to encapsulate Daoist mysticism. Constructivist standpoints, amongst others, challenged this. If each experience was created through a distinct tradition, in what sense are we (obviously) talking about something called "mysticism" in each case? Indeed, even the idea that certain exceptional experiences get to count as "religious" experiences has also been questioned. ${ }^{29}$ Some shared experiences, which may arise in our biophysical system, may be interpreted in quite different ways depending upon our predilections and context. Feelings of exhilaration, intensified heartbeat and breathing, and overwhelming joy could in a Christian Evangelical church meeting be seen as the stirrings of the spirit, on a countryside stroll with one's crush be seen as love, or experienced by an atheist witnessing a magnificent sunset on a sandy beach as simply awe before the majesty of an otherwise cold and implacable universe.

Sharf's thesis has been subject to telling critique, and here I add my own thoughts (see Excursus 6). In part, these may be the thoughts of a small child who has just had their own "spiritual experience" in a situation that is somewhat disturbing and disorientating for them. The kind of critical questions I have asked my students to ask may be one way to look at that experience: Why was this child silenced and unable to speak about what they experienced? We may discuss power and claims for legitimacy. But suggesting all such experiences are simply rhetorical ploys to claim power and legitimacy fails. That certainly was not the child's aim. While I employed discourses that allowed me to categorise and rank other people's experiences and religious traditions, this is not the whole story. That I can and have asked critical experiences about my own experience, while hardly a moral tale that can be universalized, poses problems for such a set of questions. Indeed, to suppose that any description of what appears to be what we may broadly term "spiritual experiences" (however we wish to classify them, or whether we think any such classification exists) as only linguistic exercises is itself problematic. How would we know this? What particular set of presuppositions and judgments tells us that these people are not talking about experiences of some type? Indeed, one criticism of arguments that religions, or spiritual experiences, may be universal is that this requires a bird's eye view above the world to make these judgements. But the reverse is also true. To claim absolutely that there are no sets of common experiences or categories between and across different groups also requires its own birds eye view judgement that gets outside the world to make such sweeping and vast statements. ${ }^{30}$

To try and summarise, I have become deeply suspicious of claims to spiritual authority or experiences. Nevertheless, I am equally critical of those which jump to their own universal metanarratives that no universals or even comparable traditions or experiences exist. While I would interpret much language about "marks of ultimacy" as bound up in regimes of power, authority, and lineage, I am open to the possibility that the person reporting the experience may be genuinely trying to conceptualise an experience which has the force of seemingly unquestionable "ultimacy" for them.

29 An excellent summary of such issues is Martin, "Experiences.”

30 This is a point I have made in another context, in relation to theological arguments for particularity, see Hedges, Controversies, 175, 189. Elsewhere, with reference to the work of postcolonial scholar Sara Suleri, I have also argued that the theory of utter alterity of worldviews is itself a neo-colonial standpoint that maintains a binary difference between Orient and Occident, see Hedges, "Particularities", 128. I should note that while my criticisms here are of theological categories, much that today passes for critical scholarship in the study of religion presumes the same broadly post-modern and neo-colonial basis, and so may be argued to perpetuate a white, patriarchal Orientalism in scholarship, despite its advocates often insisting the opposite - versions of this argument are in some my work in progress, see Hedges, "Engaged,” Hedges, Understanding Religion, and Hedges, "Decolonising." 


\section{Comparative and reflective comments}

I have narrated a somewhat personal set of spiritual and academic developments, and viewpoints. It is now time to ask if anything from this may be of any use or interest to anyone apart from myself. Has this been a somewhat self-indulgent venture into my own personal "mystical" and scholarly past? To seek towards some systematic clarification of the issues I will address five broad themes: 1. Methodology; 2. Studying experiences; 3. Marks of "ultimacy"; 4. Critiquing claims to "ultimacy"; and, 5. A personal reflection on being a theologian who doubts "ultimacy".

\subsection{Methodology}

While not systematically broached, this paper related to contemporary approaches that see personal narrative or autobiographical reflection as part of the scholarly apparatus. This we may relate to what is often termed the reflexive turn, which marks a move from notions of a single rationality or academic objectivity (see Excursus 5). We are all embedded in worlds of thought, and come laden with "prejudices" and experiences which lead us to interpret the world in the ways in which we do. ${ }^{31}$ My exploration here has taken a somewhat narrative approach to unpacking how not just my personal, but my burgeoning academic understandings, were conditioned by an experience at an early age. Certainly, though, the methodology has not simply said that we are shaped by these prejudices alone, and in Gadamerian hermeneutical terms we can see the questioning and opening of these horizons and prejudices in relation to a growing understanding and interpretation. ${ }^{32}$ Particularly around studying claimed ("imagined") "spiritual" or "mystical" experiences, we may certainly ask how far a researcher's own personal background plays a part in interpretation. Anthropological studies have shown that researchers engaging communities of practice (and experience) have come to be opened to such perspectives. ${ }^{33}$ We can ask broader questions about the role of personal narratives, may we say "confessions"(?), in the study of religion. Claiming academic neutrality is no longer a feasible defence for refusing to discuss one's own agenda and perspective. ${ }^{34}$ My suggestion in this piece, is that such autobiographical confession is a useful part of academic work to position any author and their prejudices and expectations.

\section{Excursus 5: The reflexive turn and objectivity}

Traditionally conceived, scholarship has tended to view the individual scholar as a free-floating, autonomous, rational, and objective subject. That is to say, it is assumed that by the use of a universal set of rational processes, the scholar can simply analyze the world around her to become closer to the "truth". In relation to what are often termed various "turns" in late twentieth century thought (variously, the linguistic turn, the reflexive turn, the critical turn, the feminist turn, etc.), such a position - associated with the Enlightenment - has been critiqued. ${ }^{35}$ As Gavin Flood puts it we are a "positioned subject." ${ }^{36}$ This involves the recognition that such factors as class, race, gender, geographical location, chronological position, and others will all affect how we think, understand, and interpret. To be reflexive is to exhibit an awareness of one's own situatedness in the construction of knowledge and one's own thinking. In the study of religion, most theory and method textbooks will not, however, advocate taking account of one's own status and reflecting

31 The term "prejudice" is here being used with reference to Hans-Georg Gadamer as the preconditions from which we know anything, rather than as inherent biases that make us inevitably distort the world we experience, see Hedges, "Gadamer," 17, and more broadly the references to philosophical hermeneutics in note 39.

32 I have argued that the terminology "opening of horizons" may be preferable to Gadamer's own "fusion of horizons" being less liable to misunderstanding and better expressing the intended conception, see Hedges, "Gadamer."

33 See Pierini, "Fieldwork," and Schmidt, "Provincializing."

34 See Flood, Beyond Phenomenology.

35 See Hedges and King, "Is the Study of Religion Religious?," 36-8, and Flood, Beyond, 35-8. See also the references in note 8. 36 Flood, Beyond, 143. 
autobiographically on this. ${ }^{37}$ Such a reflexive stance finds support from broadly social constructivist and critical theory perspectives, especially as embodied in certain functionalist approaches which seeks to show how traditions/ religions operate to maintain certain norms, ${ }^{38}$ as well as from philosophical hermeneutics which understands our situatedness and embeddedness in "prejudices". ${ }^{39}$ Notably, when such reflexivity is addressed, it is often not about personal reflection, but a more institutional reflection on the discipline and its practice. ${ }^{40}$ Perhaps this is why, as has been argued, some critical scholars are willing to criticize others with respect to the critical and reflexive turn, but are unwilling to reflect or reveal their own positionality: simply by being on the correct side of the disciplinary divide, one's position becomes, supposedly, "correct". Therefore, most critical scholars do not exemplify the kind of autobiographical and open reflexive stance that I am undertaking an advocating here. ${ }^{41}$ Importantly, I am not advocating what some may term a relativist "post-modern" approach that rejects any sense of objectivity. A critique of aspects of Enlightenment paradigms is not the same as rejection of it. A commitment to seeking to obtain objectivity and find truth is important. In this sense, I would refer to the work of Biko Agozino, who has argued for what he terms "committed objectivity," which refers to the way that one can be embedded in demands for social justice yet still seek for the truth. His work is embedded in a decolonizing approach that is particularly focused on how colonial and Western worldviews dominate and oppress many other communities. This resonates with the argument made here, which would see both personal approaches and academic approaches as not separable, and also maintains that hegemonic aspects of Western academia shape, and often distort, the study of religion. A decolonial commitment should therefore be part of a reflexive stance.

\subsection{Studying experiences}

There is much suspicion amongst academics about the meaningfulness of the terms "spiritual", "mystical", or even "experience" as academic categories. Some suggest they should be written out of study and analysis, however, we have strong reasons to question this position. This questioning runs against the dominant constructivist trend (see Excursus 6). This topic, to one side of our main issues, is nevertheless directly and intimately related. Claims to "ultimacy" may be, in at least some cases, experientially based. This is not necessarily contrary to Sharf's wider thesis: experiential authority, or claims to it, are invoked in lineage and hermeneutical questions of power and legitimacy. Such a stance is important. However, such arguments counter Sharf's claim that that is all they are. While critical of claims to "experience", we cannot simply write them off (as, for instance, solely linguistic, or assertions of power), but need a variety of perspectives to address them.

\section{Excursus 6: Religious experiences (again)}

According to Craig Martin: "The claim that humans have access to an essential, sui generis 'religious experience' is at this point no longer a viable option for scholars attempting to move beyond the uncritical, normative paradigms. ${ }^{\$ 42} \mathrm{He}$ is certainly correct that we cannot, as Rudolf Otto tried to do, access some numinous experience as a thing in itself; though as Jeppe Sinding Jensen notes Otto always lamented that language got in the way and made things concrete, as such even Otto never claimed to access the experience directly. ${ }^{43}$ However, as scholars like Shushan have contended versus Sharf's reductionism, we must allow that

37 Though Chryssides and Geaves, The Study, 82-3 does call for this reflexive approach in fieldwork.

38 Martin, A Critical, 22-26.

39 See Hedges, "Deconstructing Religion," 21-2, Hedges, "Gadamer," 17-20, and Gadamer, Truth and Method. The author is currently working on some theory which will further explore the applicability of a critical philosophical hermeneutics to the study of religion, see Hedges, Understanding Religion.

40 See King, “The Copernican,” 6-7, and Speck, "Contemporary,” 301-8.

41 See Urban, "Making," who makes this remark about Jonathan Z. Smith. This resonates well with arguments the author has argued with respect to other scholars, see Hedges, "Engaged."

42 Martin, "Experience," 537-8.

43 Jensen, "Why Magic?," 55. 
experiences do occur. ${ }^{44}$ In summary, Shushan argues that the thesis of Sharf and others are primarily based in ideological grounds and is actually contrary to the evidential data as he shows with reference to Out-ofBody (OBE) and Near-Death (NDE) experiences. I would particularly mention work by Fiona Bowie amongst others as being strongly supportive of the notion that "religious experience" can be a meaningful category with cross-cultural application. ${ }^{45}$ While Bowie, and many others, do not directly address Sharf, the overall approach of such arguments nevertheless deeply accords with what Shushan argues and underscores is the rather Western and parochial theoretical vision of Sharf's ideological approach. A decolonizing approach in the study of religion may dispute much supposedly critical scholarship. ${ }^{46}$ Moreover, Anne Taves is an example of somebody who does not abandon the study of "experiences" altogether; towards the notion that we simply access only the linguistic experience. ${ }^{47} \mathrm{Her}$ focus is on why certain experiences of some exemplary or special type are inscribed with "religious" significance. She does not posit a sui generis experience, but takes discussion of experience seriously. In scholarly terms this seems the limits of the current analytic framework, to discuss what it is that forms and leads to discussion of special experiences in particular ways. Why, at one time, might the author assume their experience is evidence of "ultimacy" but at another assume it may simply be brain experiences, and what leads them to see analogues in Zen Buddhist, Hindu tantric, and medieval Christian mystical traditions?

Moreover, if we are assessing the possibility of analysing marks of "ultimacy" across traditions, then crosscultural and comparative study is key (see Excursus 7). Shushan's work, and that of others, points to the viability of going beyond certain constructivist stances that would ascribe any experience solely to the cultural and social milieu in which it was created.

\section{Excursus 7: Comparative methodology}

Concepts of religious traditions as culturally isolated islands make no sense, while there are good reasons for seeing comparison as legitimate.$^{48}$ Arguments on this come from various strands. In his extremely deep and compelling work on comparative religion, Gavin Flood has shown that hermeneutical philosophy leads us to believe that understanding across religious and cultural borders will be possible. ${ }^{49}$ Further both Shushan and Flood note that studies in the cognitive study of religion and similar areas are, against some older paradigms, providing if not compelling then certainly very serious evidence that we need to think about commonality across human experiences that go deeper than cultural differences. ${ }^{50}$ Notwithstanding the very real and significant effects of cultural difference. As a scientific and academically credible discipline, I would suggest that academic studies in religion (theological or religious studies orientated) needs to look at the evidence and not sit within old and outdated ideological castles. Finally, the category of "religion" itself has been a matter of debate, which to some extent is related to the arguments raised above. These, equally, are involved debates which go beyond the scope of this paper. Here, therefore, I refer to work which argues that within the academic study of religion, either in areas such as religious studies or comparative theology, the category of "religion" while problematic is nevertheless capable of employment..$^{51}$

44 Shushan, "Cultural-Linguistic," 73-5, 80-3.

45 Bowie, "How to Study,” Winkelman, "Ethnological,” and Schmidt, "Provincializing.”

46 See Hedges, “Decolonising," an issue developed further in Hedges, Understanding Religion.

47 Taves, Religious Experience.

48 On the former, see Hedges, Controversies, 74, 176, on the latter see Hedges, Understanding Religion and "Comparative Methodology."

49 Flood, The Truth Within and Flood, "Religious.” A similar argument is found in Hedges, Comparative Theology, 58-66. which also discusses wider aspects of linguistic philosophy, on which also see Hedges, Understanding Religion.

50 Shushan, "Cultural-Linguistic," 79, and Flood, "Religious." I discuss some of this briefly in Hedges, Towards Better, 165-7, and it will also be explored in Hedges, Understanding Religion. See also Flood, "Religious," 134-8. Outside Religious Studies, this has been argued by leading cognitive scientists, see e.g. Pinker, The Blank.

51 Some relevant references are in notes 2 and 18. Beyond this, see my arguments on the topic in Hedges, "Comparative Methodology," Hedges, Comparative Theology, 27-39, and Hedges, Understanding Religion. 


\subsection{Marks of "ultimacy"}

Now we face the central focus of the topical issue, and therefore of this paper. How would we know "marks of ultimacy" in any tradition? I have spoken of a sense of familiarity: recognising "signs" of one's own experience. This resonates with Diana Eck's language of recognition of spirituality within the Other. ${ }^{52}$ It is, however, arguably precisely the kind of unsystematic and almost "magical" methodological weakness for which comparative studies have been critiqued and dismissed by many. ${ }^{53}$ The conception that ideas kicked off in the mind of the reader, or a sense of similar meaning, provide anything other than idiosyncratic surface resonances is certainly potent. While Arvind Sharma has argued for this as what he calls "reciprocal illumination", I have argued that this seems rather weak as a model for analytic comparative religion, though may have a potential within comparative theology where a somewhat different set of questions may be asked. ${ }^{54}$

Returning to my own personal experiences and sense of similarities, I would argue that as a comparative tool in any analytic sense they are considerably lacking. As noted, resonances were seen in areas such as Zen Buddhism, Meister Eckhart, and tantric kundalini practices. Certainly, any doctrinal sense of similarity would assuredly be missing, except arguably a notion that the absolute/ divine/ Godhead/ reality transcends all our human conceptual schemas and should be "left behind". To try and argue that this points to some common experiential basis for these claims, or any essential perennial core of "religion", would rightly be subject to many critiques. Indeed, to some extent, I would regard some of my previous reflections on these matters as what we may term "theological data" that could be analysed to see how "insiders" make sense of their own journeys. ${ }^{55}$ What we may speak of as my "imagined" sense of similarities cannot, I think, be used for two things: first, to argue for a common core spiritual experience; ${ }^{56}$ second, to argue the experiences are not in any way comparable. Perhaps it was an insight into "marks of ultimacy" across traditions? However, how would I or anyone else know that it was or was not?

\subsection{Critiquing claims to "ultimacy"}

Questions about religious experiences should include: who benefits; whose interests are served; and, what results from particular claims? ${ }^{57}$ My general argument is that we should always be critical of any claims to "ultimacy"? Further, we should be critical of our own suppositions around "knowing" what they are or how to recognise them. These are, I would suggest, some general basic academic aspects of good practice that may be invoked under the broad rubric of the hermeneutics of suspicion.

The academic study of religion has a pedigree which includes such figures as Otto who, in The Idea of the Holy (Das Heilege), saw the mystical experience as an essentially sui generis category which could be taxonomically studied and critically analysed through comparative surveys..$^{58}$ In Mircea Eliade's work, this understanding of phenomenology steeped in theological suppositions continued and became dominant across the discipline..$^{59}$ The critical turn questioned this and led, as we have discussed, to grand narratives of suspicion about comparison, the category "religion" and "religious experience", and even the existence of any meaningful comparative data outside of imaginative scholarly constructions. Recent work, though,

52 See Eck, Encountering God, 79.

53 The term magic refers to J. Z. Smiths' well-known paper, “In Comparison a Magic Still Dwells” (Imagining, 19-35). For contemporary debates, see Schmidt-Leukel and Nehring, Interreligious, and Hedges, Understanding Religion.

54 See Hedges, Comparative Theology, 66.

55 See note 9.

56 See Martin, "Experiences.”

57 Readers will no doubt hear echoes of Lincoln, "How to Read."

58 On the problematic notion of religion or religious experience as sui generis, with reference as well to Otto, see McCutcheon, Manufacturing, 14-18. See also note 6.

59 On Eliade, see McCutcheon, Manufacturing, 77-84. For wider discussions around his legacy, some more appreciative and others less so, see Schmidt-Leukel and Nehring, Interreligious. 
has in turn questioned these "truths" and suggested that both comparison and common patterns of human experiencing (not to be confused with cruder notions of some common human nature) may exist crossculturally. ${ }^{60}$ To invoke Tillichian language, the "ultimate concerns" of scholars may perhaps be held more lightly.

The concept of "ultimacy" itself can bear some theoretical and philosophical unpacking. Scholars have asked, whether the various things that diverse religious traditions term as "ultimates" are conceptually related (see Excursus 8). Further, the question can be raised as to what we are really inferring by the language of "ultimacy". In the monotheisms that relate, in varying ways, to the mythical patriarch Abraham the language of the notion of a supreme creator deity has been normative. ${ }^{61}$ However, Buddhist traditions amongst others seem to posit something quite different. The "ultimate" of Buddhism may be said to be nirvana, certainly not a creator deity. Therefore, grounds exist to question what it is we mean when we talk about "marks of ultimacy" in diverse traditions.

\section{Excursus 8: Ultimates?}

Medieval philosophical trends in the Abrahamic monotheisms, inspired by common Platonic sources, spoke of the creator deity as utterly transcendental: omnipotent, omniscient, omnibenevolent, omnipresent. ${ }^{62}$ The very language used seeks to express not just the ultimate that humans can imagine, but to posit a "meta-ultimacy" beyond all expression. Within the Buddhist traditions, however, language of nirvana while certainly seeking to express that which goes beyond all human expression or understanding, does not seem to be speaking about the same universe creating ultimate. ${ }^{63}$ It may be ultimate, but is it the same meta-ultimate? In a Christian sense, nirvana is not the all-powerful; though, on the Buddhist side the critique comes back that any god must remain within the samsaric realm, and so nirvana, signifying "going beyond" is the actual meta-ultimate. ${ }^{64}$ In some traditions and thought systems, whether it be Spinoza's philosophy or various strands of contemporary Paganism, the ultimate does not seem quite so meta-ultimate; in pantheistic systems, the "divine" is encapsulated within the world as just part of the system rather than the "meta-ultimacy" beyond it. ${ }^{65}$ Indeed, creation out of the existing primal chaos, the depths, rather than creation ex nihilo certainly seems to be the original message of the biblical record - the origins of that Abrahamic ultimate may not be "meta-ultimacy" after all. ${ }^{66}$ Whatever the case, it may be doubted if the same "ultimate" is referred to. Notably, not only religious studies scholarship asks this, and in the theology of religions a number of scholars have considered ways to conceptualise the seemingly diverse natures of ultimates. ${ }^{67}$ This paper certainly casts doubt on identifying any ultimate with the imagined deity of what became Christian orthodoxy.

$\mathbf{6 0}$ This is most particularly true of the work of Gavin Flood. See Flood, "Religious," and Flood, The Truth. These themes are taken up and explored in Hedges, Understanding Religion. Also, on comparison, see Patton and Ray, A Magic. This should also be related to studies in the cognitive science of religion, and cognitive science more broadly.

61 I avoid using Abrahamic religions here, though I think it can, in some circumstances, be legitimately used as a descriptive marker of three traditions that each see themselves inheriting the tradition of the God of Abraham. I use it here referring to medieval philosophical debates which saw much interchange. It is also used as something of a rhetorical marker, see Hughes, Abrahamic. On my notion of Abraham as a mythic patriarch, see Hedges, "What Did Kierkegaard," 73-4.

62 What is meant by deity and claims to ultimacy is often discussed within the Philosophy of Religion, see, e.g. Zagzebski, Philosophy, 77-99.

63 This is certainly notwithstanding considerable amounts of dialogical activity which has sought common ground concerning accounts of ultimacy in the two traditions. For an overview of the debates, see Harris, "Buddhism.” For some more specific debates on this from both Buddhist and Christian sides, see Abe, Buddhism and Interfaith Dialogue, Cobb and Ives, The Emptying, and Fredericks, Buddhists, 72-95.

64 We may note, though, debates on whether nirvana is a "transcendent" state or simply non-existence, see Williams, Buddhist, 34-8.

65 On various conceptions of the "ultimate" or deity, see Hedges, Towards Better, 74-7.

66 See May, Creatio. Such thought is particularly developed in Process Theology, see for instance Keller, The Face, or Griffin, God, 51-68.

67 For a discussion of related debates, see Hedges, Controversies, 109-96, 228-53. 


\subsection{A Personal reflection on being a theologian who doubts "ultimacy"}

While many of the foregoing reflections have dealt with issues that may be placed broadly within the religious studies spectrum of thought, my final section deals with more explicitly theological questions. Despite my own "mystical experience", which for many years assured me of the spiritual nature of reality, even if not of any personal deity, I have come to severely doubt whether this is what we may term a necessary hypothesis. Is there a deity or transcendent reality? I remain deeply agnostic on this score. What I am certain of, and speaking as a Christian and Anglican theologian, is that there is not some big "sky daddy" type deity who personally intervenes and answers the (selfish and self-centred) prayers of "His" devotees. ${ }^{68}$ Moreover, Jesus certainly did not regard himself as being divine in any way (how could a Jewish/ Galilean rabbi even process such a thought?) and is not to be equated with that figure which the post-Chalcedonian tradition has deemed orthodox according to its Christological standards. ${ }^{69}$ From a theologically informed standpoint, little of this is particularly new or shocking of course. Atheist Christian theology is well established through the American Death of God or British Sea of Faith schools. Doubts about everything from the virgin birth of Jesus to his divinity have likewise been widely discussed and debated for many years. I am certainly not claiming, therefore, some kind of especially revealing stance here. I am, like many others, a "heretic" if one wants to put it in those terms. ${ }^{70}$

All this leads me back, though, to the phrasing of the Call for Papers which first inspired me to respond with a reflection on the very problem of expecting to find "marks of ultimacy". A theological topic for somebody whose theology does not even know if it accepts an ultimate; and certainly not the Abrahamic meta-ultimate. Indeed, my theological work is certainly informed by my critical training and research within the field of religious studies; something which of course should be a sine qua non for anyone who broadly associates with the practice of comparative theology where I locate at least some of my work. ${ }^{71}$ Indeed, one prominent academic (and confessional) theologian has informed me that I actually do not write "theology" (as they imagine it), rather I do "the history of religions" or something else. ${ }^{72}$ So, to what extent is this theological reflection a theological reflection it may be asked? If by that I mean something that others will receive and recognise as theology. It is a question I will not try and solve here. Indeed, some may ask, to be theology, how this reflection bears weight in any confessional community of ecclesial practice (as if that were the only yardstick of theology). ${ }^{73}$ Perhaps a theologian should know what "ultimacy" is? Or, at the very least, what they would signify by "ultimacy"? If so, presumably a theologian would then know how to recognise "marks of ultimacy" when he or she saw them? Is suggesting that we really can't recognise "marks of ultimacy", should be suspicious of any conception we have of them, and suggesting that actually they may not even signify "ultimacy", a sign of bad theology? Or even something which is not theology? Or, is it (as I would argue) asking the questions that (good and conscientious) theologians should ask (today)?

68 Hedges, Towards Better, 90-95.

69 Hedges, Towards Better, 59-67. For a more in-depth and specialist discussion, see e.g. Ehrman, How Jesus.

70 The term heresy being very much an "imagined" conception to sideline alternative views.

71 See Hedges, Comparative Theology.

72 I should note in fairness that some Religious Studies scholars would argue that those like myself who also do theology are seen as not "real" Religious Studies scholars either. I may note an often-unstated prejudice here, that this mainly applies to Christian theologians who also do Religious Studies, while Buddhist, Pagan, Sikh, etc. "theologians" (using this as an inadequate but understandable shorthand) who are also scholars of their own tradition tend to be (but are not always) cut a bit more slack.

73 Indeed, Paul Knitter certainly gives an example of writing theology for those Christians who struggle with church teachings and perhaps also the institution of the church as well, see Knitter, Without the Buddha, xiii-xv. Indeed, I have also argued why particular structures whether ecclesial or academic may be problematic in terms of where we write from and to, see Hedges, Comparative Theology, 24-6. Therein, while speaking of a theological context, I make an argument for a writing of scholarship that may be "subversive", 50-3, which I would argue may also be necessary in the study of religion too. 


\subsection{Not a conclusion}

This paper has raised issues which I have not always answered. Indeed, the central focus, "marks of ultimacy", is one which I fully confess that I am not sure I am qualified to say anything on. I could have made some mundane points, such as talking about texts (people/ experiences/ etc.) which say they point to some "ultimate" reality. These could be taken as "marks of ultimacy". However, I have embarked upon a very different course of action which was using my own experience of "ultimacy", and my journey through interpreting it, to ask questions about the very meaning of even speaking about "ultimacy" in almost any sense. My aim has been to point to broadly methodological issues and questions for scholars investigating such conceptions. I do not claim that this provides the final word in this (it is certainly not the "ultimate" account of the issues). I hope only to have raised some thought provoking questions, perhaps even suggesting that the phrasing and concept of the Call for Papers is something which scholars should find worrying and troubling in many ways. Not to say, of course, that these are things they should not or cannot discuss, but in doing so they should ask deep questions about the very categories in which we frame, think, and come to know those categories.

Rather than offering any definite conclusion, I will just draw together threads from this paper which point towards ways in which, as part of an ongoing journey of scholarship, we can think about the question of "ultimacy" today. To begin, five points relating to our study of religious experiences, ultimacy, and mysticism. First, we have no access to any ultimacy. Indeed, we should credibly doubt that it has any coherent analytic usage. Second, a hermeneutics of suspicion should guide our reading of any claims to ultimacy. In particular, questions around race, gender, class, Western neo-colonial academic hegemony, hierarchical claims to legitimacy, and others should guide our reading of such claims. We have not fully discussed all of these, but they arise out of what is discussed. Third, while critical of claims to experience, we should not dismiss the possibility that genuine and deeply held experiences are being discussed. Nevertheless, we do not discuss those experiences, only the discourse that surrounds them. Fourth, we can expect that cross-cultural experiences exist, not (necessarily) as sui generis "mystical" events, but related to shared evolutionary characteristics. Therefore, it is meaningful to discuss experiences in comparative mode. Yet, I do not see how we would know that some form of "supernatural/ divine" experience did not exist. Fifth, to avoid seeking only one lens or method for exploring any claims to ultimacy or experience. What may apply in one situation, may not be an appropriate method to approach another situation. Flexibility and an interdisciplinary, or multidisciplinary, approach will give us more perspectives.

Next, I will suggest two general issues in scholarly methodology. First, we need to more seriously consider our agendas, prejudices, and personal biography as part of what we do. This is not to forsake any search for "objectivity" or "truth". However unobtainable, they should be our aim. Rather, we must realise that we can never be wholly objective, and so to be more explicit in addressing our stance (to do autobiography as a scholarly method). This is part of the reflexive turn. ${ }^{74}$ Second, to be less strongly attached to our methods and criticisms of other scholars. Every generation, and style, of scholarship has had its own truths, certainties, and blind spots. Ours is no different. To be dogmatic or ideological will, I believe, do us no favours. Too often, I believe, scholars hold to their way of doing scholarship as an "ultimate." We should be as critical of this, as any religious claim to ultimacy.

\section{References}

Abe, Masao. Buddhism and Interfaith Dialogue. Edited by Steven Heine. Honolulu, HA: University of Hawai'i Press, 1995. Agozino, Biko. “Committed Objectivity in Race-Class-Gender Research.” Quality and Quantity 33:4 (1999), 395-410. Anderson, Benedict. Imagined Communities: Reflections on the Origen and Spread of Nationalism. London and New York, NY: Verso, 1983.

74 See Flood, Beyond Phenomenology. 
Bowie, Fiona. "How to Study Religious Experience: Historical and Methodological Reflections on the Study of the Paranormal." In The Study of Religious Experience: Approaches and Methodologies, edited by Bettina Schmidt, 13-32. Sheffield: Equinox, 2015.

Boyer, Pascal. Religion Explained: The Evolutionary Origins of Religious Thought. New York: Basic Books, 2001.

Chryssides, George and Ron Geaves. The Study of Religion: An Introduction to Key Ideas and Methods. $2^{\text {nd }}$ edn. London and New York, NY: Bloomsbury, 2014.

Cobb, John and Christopher Ives, eds. The Emptying God: A Buddhist-Jewish-Christian Conversation. Maryknoll, NY: Orbis, 1990.

Eck, Diana. Encountering God: A Spiritual Journey from Bozeman to Banaras. Boston, MA: Beacon Press, 1993.

Ehrman, Bart. How Jesus Became God: The Exaltation of a Jewish Preacher from Galilee. New York, NY: HarperOne, 2014.

Fitzgerald, Timothy. Discourse on Civility and Barbarity: A Critical History of Religion and Related Categories. Oxford: Oxford University Press, 2007.

Flood, Gavin. Beyond Phenomenology: Rethinking the Study of Religion. London and New York, NY: Cassell, 1999.

Flood, Gavin. The Truth Within: A History of Inwardness in Christianity, Hinduism, and Buddhism. Oxford: Oxford University Press, 2013.

Flood, Gavin. "Religious Practice and the Nature of the Human”. In Interreligious Comparisons in Religious Studies and Theology, edited by Perry Schmidt-Leukel and Andreas Nehring, 130-41. London and New York, NY: Bloomsbury, 2016.

Forman, Robert. Mysticism, Mind, Consciousness. Albany, NY: State University of New York Press, 1999.

Fredericks, James. Buddhists and Christians: Through Comparative Theology to Solidarity. Maryknoll, NY: Orbis, 2004.

Gadamer, Hans-Georg. Truth and Method. Trans. by William Glen-Doepel. London: Sheed and Ward, 1979.

Griffin, David Ray. God and Religion in the Postmodern World: Essays in Postmodern Theology. Albany, NY: State University of New York Press, 1989.

Harris, Elizabeth, Paul Hedges, and Shantikumar Hettiararchi, eds. Twenty-First Century Theologies of Religions: Retrospection and Future Prospects. Leiden: Brill, 2016.

Hedges, Paul. "Particularities: Tradition-Specific Post-Modern Perspectives." In Christian Approaches to Other Faiths, edited by Paul Hedges and Alan Race, 112-35. London: SCM, 2008.

Hedges, Paul. Controversies in Interreligious Dialogue and the Theology of Religions. London: SCM, 2010.

Hedges, Paul. "Discourse on the Invention of Discourse: Why We Still Need the Language of 'Religion' and 'Religions." Journal of Religious History, 38:1 (2014), 132-48.

Hedges, Paul. “Is Christianity the Only True Religion? A Theology of Radical Openness to Religious Others.” Interreligious Insight 12:2 (2014), 34-42.

Hedges, Paul. “Gadamer, Play, and Interreligious Dialogue as the Opening of Horizons.” Journal of Dialogue Studies 4 (2016), 5-26.

Hedges, Paul. “Comparative Methodology and the Religious Studies Toolkit.” In Interreligious Comparisons in Religious Studies and Theology, edited by Perry Schmidt-Leukel and Andreas Nehring, 17-33. London and New York, NY: Bloomsbury, 2016.

Hedges, Paul. "What Did Kierkegaard Intend? On the Ethics of Belief and the Failure of Fear and Trembling's Abraham." In Facing Abraham: Seven Readings of Søren Kierkegaard's Fear and Trembling, edited by Frederiek Depoortere, 71-98. Leuven: Peeters, 2017.

Hedges, Paul. "Multiple Religious Belonging after Religion: Theorising Strategic Religious Participation in a Shared Religious Landscape as a Chinese Model." Open Theology 3 (2017), 48-72.

Hedges, Paul. Towards Better Disagreement: Religion and Atheism in Dialogue. London and New York, NY: Jessica Kingsley Publishing, 2017.

Hedges, Paul. Comparative Theology: A Critical and Methodological Perspective. Leiden and Boston, MA: Brill, 2017.

Hedges, Paul. "Deconstructing Religion: Some Thoughts on Where We Go from Here - A Hermeneutical Proposal." Exchange 47:1 (2018), 5-24.

Hedges, Paul. "Decolonising the Study of Religion (and the Social Sciences and Humanities)." (2018). Available at: www. logosdao.wordpress.com/2018/03/12/decolonising-the-study-of-religion-in-relation-to-the-social-and-humansciences/.

Hedges, Paul. Understanding Religion: Theories and Methods for Studying Religiously Diverse Societies (working title). Berkeley, CA: University of California Press (under contract, due 2019).

Hedges, Paul. "Engaged Scholarship as the Study of Religion, or on Being a Scholar-Activist: The Contribution of Interreligious Studies." In Religion and Politics in the Crisis of Engagement: Towards the Relevance of Intercultural Theology and Interreligious Studies (draft title), edited by Norbert Hintersteiner. TBC (publication under review).

Hedges, Paul and Anna King. "Is the Study of Religion Religious? How to Study Religion and Who Studies Religion." In Controversies in Contemporary Religion: Education, Law, Politics, Society, and Spirituality, edited by Paul Hedges, vol. 1, 31-56. Santa Barbara, CA: Praeger, 2014.

Hick, John. An Interpretation of Religion: Human Responses to the Transcendent. Basingstoke: Macmillan, 1989. Hughes, Aaron. Abrahamic Religions: On the Uses and Abuses of History. Oxford: Oxford University Press, 2012. 
Jawad, Haifaa. "A Muslim Response to the Christian Theology of Religions.” In Twenty-First Century Theologies of Religions: Retrospective and Future Prospects, edited by Elizabeth Harris, Paul Hedges, and Shanthikumar Hettiarachchi, 328-58. Leiden and Boston, MA: Brill, 2016.

Jensen, Jeppe Sinding. “Why Magic? It's Just Comparison." Method and Theory in the Study of Religion 16:1 (2004), 45-60.

Katz, Stephen. Mysticism and Religious Traditions. Oxford: Oxford University Press, 1983.

Keller, Catherine. The Face of the Deep: A Theology of Becoming. Abingdon and New York, NY: Routledge, 2002.

King, Anna and Paul Hedges. "What is Religion? Or, What is it We are Talking About?" In Controversies in Contemporary Religion: Education, Law, Politics, Society, and Spirituality, edited by Paul Hedges, vol. 1, 1-30. Santa Barbara, CA: Praeger, 2014.

King, Richard. "Mysticism and Spirituality." In The Routledge Companion to the Study of Religion, edited by John Hinnells, 323-38. $2^{\text {nd }}$ edn. London and New York, NY: Routledge, 2010.

King, Richard. "The Copernican Turn in the Study of Religion." In Religion, Theory, Critique: Classic and Contemporary Approaches and Methodologies, edited by Richard King, 1-20. New York, NY: Columbia University Press, 2017.

Knitter, Paul. Without Buddha I Could Not be a Christian. Oxford: Oneworld, 2009.

Lincoln, Bruce. "How to Read a Religious Text: Reflections on some Passages from the Chandogya Upanisad." History of Religions 46:2 (2006), 127-39.

Lincoln, Bruce. Gods and Demons, Priests and Scholars: Critical Explorations in the History of Religions. Chicago: The University of Chicago Press, 2011.

Lindbeck, George. The Nature of Doctrine: The Church in a Postmodern Age. Philadelphia: Westminster Press, 1984.

Luhrmann, Tanya. "Building on William James: The Role of Learning in Religious Experience." In Mental Culture: Classical Social Theory and the Cognitive Science of Religion, edited by Dimitris Xygalatas and William McCorkle, Jr., 145-63. Durham and Bristol, CT: Acumen, 2013.

McCutcheon, Russell. Manufacturing Religion: The Discourse on sui Generis Religion and the Politics of Nostalgia. Oxford: Oxford University Press, 1997.

Martin, Craig. A Critical Introduction to the Study of Religion. $2^{\text {nd }}$ edn. London and New York: Routledge, 2017.

Martin, Craig. "Experience." In The Oxford Handbook of the Study of Religion, edited by Michael Stausberg and Steven Engler, 525-40. Oxford: Oxford University Press, 2016.

May, Gerhard. Creatio ex Nihilo: The Doctrine of “Creation out of Nothing” in Early Christian Thought. Edinburgh: T \& T Clark, 1994

McCutcheon, Russell. Critics Not Caretakers: Redescribing the Public Study of Religion. Albany, NY: State University of New York, 2001.

McCutcheon, Russell. The Discipline of Religion: Structure, Meaning, Rhetoric. London and New York, NY: 2003.

Mitchell, Claudia, editor. Just Who Do We Think We Are? Methodologies for Autobiography and Self-study in Education, Abingdon and New York, NY: Routledge, 2005.

Oldmeadow, Harry. "Metaphysics, Theology and Philosophy." Sacred Web 1 (1998).

Otto, Rudolf. The Idea of the Holy. Translated by John Harvey. Oxford: Oxford University Press, 1958.

Patton, Kimberley and Benjamin Ray, editors. A Magic Still Dwells: Comparative Religion in the Postmodern Age. Berkeley, CA: University of California Press, 2000.

Pierini, Emily. "Fieldwork and Embodied Knowledge: Researching the Experiences of spirit Mediums in the Brazilian Vale do Amanhecer." In The Study of Religious Experience: Approaches and Methodologies, edited by Bettina Schmidt, 55-70. Sheffield: Equinox, 2015.

Pinker, Stephen. The Blank Slate: The Modern Denial of Human Nature. London and New York, NY: Penguin, 2002.

Schmidt, Bettina, editor. The Study of Religious Experience: Approaches and Methodologies. Sheffield: Equinox, 2015.

Schmidt, Bettina. "Provincializing Religious Experience: Methodological Challenges to the Study of Religious Experience in Brazil." In The Study of Religious Experience: Approaches and Methodologies, edited by Bettina Schmidt, 88-101. Sheffield: Equinox, 2015.

Schmidt-Leukel, Perry. God Beyond Boundaries: A Christian and Pluralist Theology of Religions. Münster: Waxmann, 2017.

Schmidt-Leukel, Perry. "Pluralisms: How to Approach Religious Diversity Theologically." In Christian Approaches to Other Faiths, edited by Paul Hedges and Alan Race, 85-110. London: SCM, 2008.

Schmidt-Leukel, Perry and Andreas Nehring, editors. Interreligious Comparisons in Religious Studies and Theology. London and New York, NY: Bloomsbury, 2016.

Sharf, Robert. "Buddhist Modernism and the Rhetoric of Meditative Experience." Numen, 42:3 (1995), 228-83.

Sharf, Robert. “Experience.” In Critical Terms for Religious Studies, edited by Mark C. Taylor, 94-116. Chicago: University of Chicago Press, 1998.

Shushan, Gregory. "Cultural-Linguistic Constructivism and the Challenge of Near-Death and Out-of-Body Experiences." In The Study of Religious Experience: Approaches and Methodologies, edited by Bettina Schmidt, 71-87. Sheffield: Equinox, 2015.

Smith, Aaron. Thinking about Religion: Extending the Cognitive Science of Religion. Basingstoke: Palgrave Macmillan, 2014. Smith, Jonathan Z. Imagining Religion: From Babylon to Jonestown. Chicago: University of Chicago Press, 1982. 
Speck, Simon. "Contemporary Social Theory and Religion: The Misconstrual of Religion in Theories of 'Second' Modernity." In Religion, Theory, Critique: Classic and Contemporary Approaches and Methodologies, edited by Richard King, 297-314. New York, NY: Columbia University Press, 2017.

Taves, Ann. Religious Experience Reconsidered: A Building-Block Approach to the Study of Religion and Other Special Things. Princeton, NJ: Princeton University Press, 2011

Taylor, Charles. Modern Social Imaginaries. Durham, NC: Duke University Press, 2003.

Urban, Hugh B. "Making a place to stand: Jonathan Z. Smith and the politics and poetics of comparison." Method and Theory in the Study of Religion, 12:4 (2000), 339-78.

Wilkins, Ruth. "Taking it Personally: A Note on Emotion and Autobiography." Sociology, 27:1 (1993), 93-100.

Williams, Paul with Anthony Tribe and Alexander Wynne. Buddhist Thought: A Complete Introduction to the Indian Tradition. $2^{\text {nd }}$ edn. London and New York, NY: Routledge, 2012.

Winkelman, Michael. "Ethnological and Neurophenomenological Approaches to Religious Experiences." In The Study of Religious Experience: Approaches and Methodologies, edited by Bettina Schmidt, 33-51. Sheffield: Equinox, 2015.

Woods, Richard, editor. Understanding Mysticism. London: The Atholone Press, 1981.

Zagzebski, Linda. Philosophy of Religion: An Historical Introduction. Oxford: Blackwell, 2007. 